\title{
Reversing Racism and the Elite Conspiracy: Strategies used by British National Party Leader in Response to Hostile Media Appearances
}

\author{
Andrew J. Johnson ${ }^{1}$ and Simon Goodman ${ }^{2}$ \\ ${ }^{1}$ Psychology Research Centre, \\ Bournemouth University, \\ Poole, \\ UK \\ ${ }^{2}$ Department of Psychology and Behavioural \\ Sciences, \\ Coventry University \\ Coventry, UK
}

Corresponding Author: Andrew J. Johnson

Address for Correspondence: Psychology Research Centre Bournemouth University Fern Barrow

Poole

BH12 5BB

Email: andjohnson@bournemouth.ac.uk

Word count: 8,754 (including references) 


\begin{abstract}
This paper addresses the talk of the leader of the British National Party leader, Nick Griffin, when he spoke on the BBC following a surge in electoral success for the party. Inclusion in these programmes demonstrated political progress for the BNP, yet ironically facilitated breadth of criticism for the party, as his appearances were met with widespread hostility and accusations of extremism. Reactive rhetoric to these criticisms is central to Griffin rebranding the party and becoming part of mainstream UK politics. Discourse analysis is used to explore how Griffin responds to such criticism during two radio programmes and one television programme between 2009 and 2010. The analysis shows how Griffin uses two interconnected strategies of (1) presenting British people as the victims, rather than the perpetrators, of racism, and (2) blaming this racism not on outside groups, but on an ill-defined 'ruling elite'. These strategies are not independent of one another and function in response to criticism to present Griffin and the BNP as not racist aggressors but respondents to anti-white racism. The implications of this strategy for the presentation and attempted rebranding of the BNP, alongside other far right and mainstream parties, are discussed.
\end{abstract}

\title{
Key Words
}

Racism; Racism denial; Far-right; British National Party; Discourse analysis 


\section{Introduction}

\subsection{Background}

The British National Party (BNP) ${ }^{1}$ is the most electorally successful far-right political party in British electoral history (Ford and Goodwin, 2010). Formed from a range of far-right groups in 1982 (Copsey, 2004), the party has moved away from neoNazi/National Front antecedents and sought legitimacy through modernisation and moderation of rhetoric (Wood and Finlay, 2008; Edwards, 2012). This can be contrasted with the relatively new far-right English Defence League (EDL), where their violent street protests are viewed as a threat to social cohesion (Treadwell, 2012). However, despite seeking mainstream legitimacy the BNP continues to advocate voluntary repatriation of all non-whites in the UK and the reintroduction of corporal and capital punishment and, in addition, vehemently opposes both immigration and what it calls the Islamic 'colonisation' of the $\mathrm{UK}^{2}$. Following the election of Nick Griffin as party Chairman in 1999, Griffin has shifted the party away from the position of electoral indifference espoused by the hardliner incumbent Tyndall (Copsey, 2007) by actively seeking electoral success.

Central to the modernisation agenda, Copsey (2007) describes how the party underwent a process of 'fascism recalibration', wherein the BNP focussed on adopting an appearance of responsibility. Rhodes (2009) highlights how, as part of this strategy, the party has focused on (relatively banal) local issues (see also Halikiopoulou and Vasilopoulou, 2010). This focus enabled the party to appear respectable and less focussed on issues of race. However, the party nevertheless identifies inequality within a local context as related to non-white individuals (Copsey, 2004), allowing opposition to these individuals to appear to be resourcebased rather than racially motivated. In line with this strategy of 'fascism recalibration', Billig (2012) argues that contemporary fascist groups adopt a dual strategy where lip-service is publically paid to moderation/respectability. However, in private, this can be contrasted with a more extreme message.

Ford and Goodwin (2010) identify three main strategies that can explain the rise in electoral popularity of the BNP. First, the party has obtained local credibility by

\footnotetext{
${ }^{1}$ http://www.bnp.org.uk/

${ }^{2}$ http://communications.bnp.org.uk/ge2010manifesto.pdf
} 
canvassing on issues of importance to local residents. Second, inspired by Le Pen's Front National in France, the BNP adopted a policy of moderation. Griffin, a middle class Cambridge graduate, is not the archetypal image of a far-right activist; under his lead, party rhetoric shifted from overt references of race/colour (Copsey, 2007). It is argued that the BNP have attempted to replicate the rhetoric of another successful right wing party, the United Kingdom Independence Party (UKIP), wherein nationalist ideals are promoted through notions of self-determination and economic prosperity (Halikiopoulou and Vasilopoulou, 2010).

Third, Ford and Goodwin (2010) argued that the party has focused upon particular groups in society. This is evidenced from their survey work illustrating that the strongest support for the party is found in older, less educated, working class men, living in declining industrial towns (see also, Deary, Batty, and Gale, 2008). In contrast, Rhodes (2011) has argued that it is an oversimplification to associate the party uniquely with the 'white working class.' Specifically, when BNP membership lists were leaked in 2008, Woodbridge (2010) highlights how the supporters were more diverse than the conventional caricature of BNP voters, including: teachers, clergy, police constables, police officers, and soldiers.

This electoral appeal of the BNP over the last 10 years is evidenced by the $0.7 \%$ and 1.9\% share of the vote in the 2005 and 2010 UK National General Elections, respectively; a total of fifty-five councillors following the 2008 local elections; and the two European Members of Parliament gained in the 2009 European Elections with almost 1 million votes (although, as noted by Renton, 2005, employment of proportional representation in European elections benefits smaller parties such as the BNP). Edwards (2012) argued a growth in party confidence has emerged following electoral success with increased use of the party name within the 2010 manifesto (compared to 2005). Rhodes' (2009) analysis of BNP voters emphasise the respectably commonplace stance of the party where most voters report (trivial) local issues as a rationale for voting BNP rather than far-right ideologies, a point supported by Ford and Goodwin (2010) who argue that the BNP have successfully addressed the concerns of many voters regarding immigration; an issue that major political parties are perceived to have inadequately tackled. Furthermore, the party have exploited ideological divisions following the perceived rise in radical Islam (Ford and Goodwin, 2010). 


\subsection{Discursive psychology and the talk of the far-right}

What Copsey has termed 'fascism recalibration' (2007) is a discursive accomplishment; that is, the rhetoric of the BNP has been changed so as to present the party in a more sympathetic light and as a champion of the British people rather than as a racist organisation. As a result of this, there is a need for discourse analysts to investigate the developing rhetoric of the far-right. Discursive analysts (e.g. Edwards and Potter, 1992) focus on the 'action orientation' of talk. In this context, one does not attempt to ascertain what members of far-right organisations think, since they have an interactional requirement (or 'stake,' Edwards and Potter, 1992) to not appear racist. Instead, they focus on what these speakers are doing and accomplishing through the language used. Discourse analyses have shown that speakers (and members of institutions) go to rhetorical lengths to distance themselves from being presented as prejudicial because there is a cultural 'taboo against prejudice' (Billig, 1988, p.95) where any prejudice is viewed as irrational (Edwards, 2003). As a result of this, Condor (2000) has argued that focussing on the ways in which people present themselves in conversations is an important area of study: "Although impression management is often treated simply as an empirical inconvenience - a potential source of bias in questionnaire-based research on ethnic attitudes - some researchers, particularly those working with conversational data, have treated this as a topic for research in its own right" (Condor, 2000, p.176).

A number of studies have been conducted on extreme right-wing rhetoric in Europe. Van Dijk (1992, p.94) shows how the strongest form of denying racism is what he terms a 'reversal' which can take the form 'we are not the racists, they are the real racists'. Van Dijk (1992) highlighted how the French National Front used this strategy by claiming that immigration constitutes anti-French racism and the 'antiracists' are, paradoxically, inducing racism through tolerating immigration. Rooyacker and Verkuyten (2012) showed how Dutch far-right leader Geert Wilders presented himself as more typical of the Dutch people than other political leaders in the country. Van der Valk (2003) identified a number of arguments used in French right-wing discourse to oppose immigration, these included: the government being a soft touch on the issue, immigrants being a cause of unemployment, and immigrants being too different culturally to the French. All of these arguments include aspects of what Augoustinos and Every (2007) term 'discursive deracialisation', where any racial 
motive for opposing outgroups is removed and replaced with seemingly non-racist arguments (see also Goodman and Burke, 2011). Verkuyten (2012) highlights how this distinction is further nuanced in anti-Islam discourse through making a distinction between Islam as a faith/ideology and Muslims as a people; this serves to mitigate accusations of prejudice as criticism is directed to an abstract construct rather than individuals.

Despite this focus in Europe, few discursive studies have looked at far-right groups in the UK since Billig's (1978) seminal work on the BNP's predecessors (the National Front). Two exceptions are analyses of the BNP website by Atton (2006) and Wood and Finlay (2008). Atton showed that the BNP consistently disclaims that it is racist, but instead is concerned with preserving British culture, which is presented as under threat. Wood and Finlay's analysis concerned articles produced by the BNP in the month following the 2005 London bombings. They showed how the BNP categorised Muslims as a homogenous entity wherein their potential threat to British culture is uniform. The bombings are described by Barnes (then Director of the BNP Legal Department) as "genocidal hate crimes", a proposition that identifies white people as the victims. This enables the BNP to position themselves as respondents to anti-white racism rather than acting as racial aggressors. Through identifying Muslims as racist, the BNP implicitly suggest that racism is undesirable; this serves to contrast their stance with the association of bigotry to the far-right. Indeed, van Dijk (1992) proposes that "the strongest form of denial is reversal" (p.94).

The current analysis builds upon these past studies by examining the strategies used by Griffin to counter accusations of extremism. Mainstream political media appearances by the BNP (and Griffin in particular) are noteworthy due to their rarity. These appearances present an acute challenge to Griffin: the party requires greater media exposure in order to be accepted as mainstream, however, inclusion in the mainstream media results in hostile critique of the party. This criticism has the potential to both deter possible future voters and discourage some current voters due to highlighting the flaws of a previously opaque protest vote. Consequently, how Griffin responds to this criticism will determine whether the party can be accepted within mainstream political dialogue. In this context, Griffin is not able to frame his position in his own terms (as one might on the party website) but must be reactive to 
the accusations of others. Therefore, this research will examine the strategies used by Griffin to justify policy in the context of media hostility.

\section{Methodological Procedure}

The data used in this study is gathered from three high profile BBC programmes that Nick Griffin, participated in. Data were selected from the BBC as the public service broadcaster is responsible for impartiality. While this may appear to be a small corpus, it is rare for Griffin to appear in mainstream UK media, perhaps because, as the analysis shows, Griffin is particularly critical of the BBC. The three programmes are Radio Four's 'Today'3 (8th June 2009), BBC One's 'Question Time'4 (22nd October 2009), and Radio Five Live's Breakfast programme 5 (19th April 2010). Both 'Today' and 'Question Time' are considered to be heavyweight political programmes in the UK. Griffin's Radio 4 appearance occurred the morning after the 2009 European elections, in which the BNP obtained two seats in the European Parliament. Griffin's appearance on Question Time was especially controversial and resulted in widespread media coverage, with the programme attracting viewing figures of 8 million ${ }^{6}$; more than a 50\% share of the total television viewing on the night it was broadcast. The Question Time appearance coincided with a court case examining the legality of BNP membership criteria ("whites only"). The Radio Five Live appearance comprised a radio phone-in during the build up to the 2010 UK General Election. These programmes resulted in approximately 100 minutes of data. This data is part of a larger scale project and in this current paper no extracts were selected from the third source.

The data was collected and transcribed by the first author. A simplified Jeffersonian approach to transcription (Clarke, Kitzinger, and Potter, 2004) was used; this allows

\footnotetext{
${ }^{3}$ The full interview is available here: http://news.bbc.co.uk/today/hi/today/newsid 8088000/8088793.stm Last accessed 26/11/12 ${ }^{4}$ http://www.bbc.co.uk/programmes/b00nft24. Last accessed 26/11/12. The programme can be found on youtube.

${ }^{5}$ The full interview is available here (beginning at 5 minutes 12 seconds into the file) http://www.bbc.co.uk/programmes/b00s1tlr Last accessed 26/11/12

${ }^{6}$ http://www.guardian.co.uk/politics/2009/oct/23/bbc-anxiety-nick-griffin Last accessed 26/11/12
} 
for major features of the talk to be represented ${ }^{7}$. The analysis, conducted by both authors, followed a critical discursive psychological approach (e.g. Wetherell, 2003). Such an approach is ideal in this context as it allows for a detailed actions orientation focussed analysis advocated from the discursive psychological position (Edwards and Potter, 1992), but is also explicitly political in terms of the research aims (i.e. to understand the far right) and the implications of the talk being analysed. This is what Wetherell describes as "the social and political consequences of discursive patterning" (Wetherell, 1998, p.405). Therefore, the analysts focussed on what Griffin is accomplishing by saying what he does, rather than making claims about what he may or may not 'really' be thinking. In terms of the 'social and political consequences' of the talk, consideration is given to how Griffin's responses to hostile questioning present him and his party as not extreme, with the ultimate aim of increasing electoral support. In the analysis, recurrent strategies were identified that were used to counter hostile questions. In the analysis section, the extracts that are presented are those which most clearly illustrate and represent the strategies that are identified throughout the wider corpus ${ }^{8}$.

\section{Results and Analysis}

In this analysis it is shown how two interrelated strategies (1. presenting 'indigenous' British people as victims of anti-white racism, and 2. constructing an amorphous liberal elite for whom to blame for this anti-white racism) are used to account for Griffin and BNP's far-right, and controversial, position. As these two strategies are used together to achieve the same end, they are analysed concurrently.

The first extract, in which Griffin is being interviewed by John Humphries (JH), contains a clear example of Griffin using these two strategies together.

\section{(1) Radio 4 interview:}

1. J.H. oh, it's obsessed with race to say that (.) there's n- something $\underline{\text { not }}$

2. (.) quite (.) right let's put it no more strongly than that there's

3. something not (.) quite (.) white (.) er er by in in saying that erm if

\footnotetext{
${ }^{7}$ In the extracts underlining represents emphasis, (.) represents a pause, square brackets represent overlapping speech, and words in italics represents additional non spoken information.

${ }^{8}$ Readers are invited to watch and/or listen to the extracts by following the web links provided.
} 
4. you are black or asian you cannot join (.) this national (.) political party

5. (.) slightly different I think from the metropolitan police black $u$

6. officers association wouldn't you say?

7. (.)

8. N.G. I don't think it's different in the slightest because as the simple fact

9. $\quad$ is as I say that white police officers couldn't set up an association

10. of their own er if for instance they feel they're being overlooked for

11. ap- prom for promotion so every different ethnic group er in

12. this (.) multicultural multiethnic society that our masters have imposed

13. on us they're all allowed groups to stand up on their behalf but

14. the indigenous majority aren't there's the bias the bias is the

15. consequence of the decisions of the political elite not us

The extract begins with the interviewer challenging Griffin's BNP for being potentially racist by highlighting the party's exclusionary entry requirements. This challenge is made in an explicitly delicate way; such delicacy follows on from Griffin's claim that the BBC is 'obsessed with race'. Griffin rejects JH's comment, despite it being formulated so as to receive a 'yes' response (wouldn't you say?; see Clayman and Heritage, 2002). Not only does Griffin reject JH's point, but he uses it to highlight an 'inequality' between Black ('they' 13) and White ('indigenous majority' 14) police officers, where Blacks have the rights (to 'stand up' for themselves 10-11) and Whites are oppressed. This is an example of positioning White people as the victims of racism (strategy one); an approach that has been shown to be undertaken by the far right generally (van Dijk, 1992) and specifically by the BNP with regard to Muslims (Wood and Finlay, 2008). Griffin attempts to present this point as obvious (Edwards and Potter 1992) by referring to it as a 'simple fact' (8).

However, Griffin uses this strategy in conjunction with blaming an 'elite' for this problem (strategy two). Rather than blaming minorities (such as Black police officers in this case) Griffin refers to the 'political elite' (15) an ill-defined outgroup ('not us' 13) who are presented as being responsible for this problem (i.e. multiculturalism and subsequent anti-white racism). The elite are referred to as 'our masters' and it is this group who are presented as having agency, not the indigenous people ('imposed on $u s^{\prime}$ 12-13). This imposition suggests that the British people did not want this, were not 
consulted on it, and are disadvantaged by living in a multicultural society. By using these two strategies simultaneously Griffin is able to make this contentious claim without directing any accusation towards Black (or other non-White) groups, i.e. the criticism becomes political (focussed on the predominantly white decision-makers) and not directly racial.

Later in the same interview, Griffin again uses these two strategies together, this time following a discussion about Apartheid era South Africa.

\section{(2) Radio 4 interview}

1. J.H. But in every other respect apartheid was acceptable?

2. (1.0)

3. N.G. no absolutely not an what's more it's in a different country an

4. awful long way aw-way it's about one group being second class

5. citizens and the other group being on top an in this country which is

6. where we are today it's the (.) indigenous majority who are th

7. second class citizens in every possible sphere not as a

8. consequence of the immigrants themselves but because our ruling

9. elite has made us second class and that's one reason why we've

10. got such a huge vote in the north of England

11. J.H. so we (.) are (.) second class citizens in this country notwithstanding

12. not the fact that er er houses of parliament both houses of

13. parliament are overwhelmingly white notwithstanding the fact that the

14. cabinet is overwhelmingly white and so on we are second class citizens

15. in our own country are we?

16. (1.0)

17. N.G. I don't feel that the liberal elite running the BBC are second class

18. citizens

19. No [but if you go (.) to: ordinary working ] ordinary

20. J.H. [are you obsessed with the BBC just a little bit?]

21. N.G. working class (.5) er no i'm being interviewed by the BBC and

22. as always asked the same damn four questions er so I get a bit

23. sick of the BBC haven't slept all night but if you come (.) to

24. places like Bradford places like Oldham and talk to ordinary people 
25. there actually not just white people also say Sikhs and Hindus

26. you will find that they have very serious problems living in this

27. multiracial multicultural society where the ruling establishment (.)

28. the media the politicians and the police force do not take anti

29. white racism seriously

This extract begins by JH implying that Griffin would support South African apartheid (1) in a way that invites a 'no' response, which is exactly how Griffin responds (3). However, Griffin then goes on to draw parallels with the treatment of Black South Africans and indigenous British people (see Edwards, 2012) by suggesting that the 'indigenous majority' (6) ('we') are treated badly in relation to 'them', the immigrants (8). It is this favouring of 'them' over the British 'us', highlighted through the use of the extreme case formulation 'every possible sphere' (7), that is used to account for the BNP's success (9-10). JH challenges Griffin's claim by repeating his phrases that 'we are second class citizens' (14), a strategy that has been used to show up previously made comments (Antaki and Leudar 2001), and by providing examples that disprove this. As in the previous extract, Griffin first makes a claim about British people being the victims of prejudice and then shifts to directing the blame for this onto an 'elite'.

When this 'elite' is first referred to, JH does not question the concept; instead, he pursues and challenges the point about British people being second class citizens (1115). Griffin responds to this in two ways: the first is to reassert his claim that British people are not perpetrators, but victims, of prejudice in what he describes as 'antiwhite racism' (28-29). In making this claim Griffin draws upon support from 'Sikhs and Hindus' (25) to present himself (and the party) as relevant to multi-ethnic groups (anonymous authors, under review); this serves also to disguise a racial agenda, since other ethnic groups share this view. Griffin then uses a three-part list to describe the organisations that do nothing to stop this racism. However, again this strategy is not used independently and draws additionally upon the second strategy. He does this by suggesting that the BBC (who are hosting the interview) are part of this ruling elite, and so are not part of the ingroup who are second class citizens. Here Griffin refers to this 'ruling' elite as a 'liberal' (17) elite and contrasts this new outgroup with the 'ordinary working class' so that an additional 'us and them' distinction is made (now 
both the indigenous White British 'us' and the foreign 'immigrant' them and ordinary working people 'us' and the ruling/liberal elite 'them'). Once more while the 'immigrant' 'them' is presented as problematic it is the other group, the ruling elite, which are positioned as responsible for this. This again allows Griffin to criticise the existence of immigrants without directly attacking them, and thus not appearing overtly racist.

Rather than addressing Griffin's point about the elite, JH takes a different line of inquiry and asks him about his interest in the BBC. This perhaps could be expected as an employee of the BBC has a stake and interest (Edwards and Potter, 1992) in the positive presentation of the BBC. Griffin's response to this question is unusual for a standard news interview as he criticises the $\mathrm{BBC}$ for its alleged narrow line of inquiry. His use of the word 'damn' (22) is unusually strong for this context, as is his claim that he gets sick of the BBC (22-23). His following comment that he has not slept all night (23) could suggest an orientation to his previous remark as inappropriate for this context. Griffin then continues to build his case against the outgroup, now referred to as the 'ruling establishment' (27), for not preventing the anti-white racism he claims to be working against. This 'establishment' includes the media, which again implicates the $\mathrm{BBC}$ and may be used to further suggest that he is not getting a fair interview. Politicians and the police are also included in this establishment. JH does not respond to Griffin's point and instead begins a new question following this turn.

The following extract is from Question Time and shows Griffin in discussion with a number of panel members (Jack Straw, Bonnie Greer, Baroness Warsi, and Chris Hume, alongside the presenter David Dimbleby) where he again uses the two strategies of presenting Whites as the victims of racism and blaming this racism on the ruling elite together. As this is an extended extract it is broken into sections for clarity.

\section{(3A) $Q T$}

1. N.G. Jack Straw was actually right (.) I think on this when he

2. said that no it's not the labour party's fault (0.5) it's the fault of the

3. $\quad$ entire (.) political (.) elite which has imposed an enormous

4. $\quad$ multicultural (.) programme (.) experiment on the British people (.) 
5. without so much as a (by you leave) (.) all we've got out of it is tax

6. bills (.) it's transformed our country (.) to the extent that the

7. government's own figures (.) er interpreted by demographers

Griffin categorises all three main political parties (Labour and Conservative as well as the Liberal Democrats, but not the BNP) as being part of a wider 'political elite'. This is similar to the 'elite' referred to in the previous extracts. This elite, including the political parties, is presented as once more 'imposing' (3) the problem on the British people against their will and to their detriment (5-6). Griffin presents this elite as the outgroup by referring to 'our country' (6) which is contrasted with 'them', the elite. The mention of the problematic and controlling elite is once more used alongside the strategy of presenting British people as the victims of prejudice, but again it is this elite, rather than non-British people who are blamed for this. Again, the term 'imposed' (3) is used to suggest that British people do not want multiculturalism. This time the term 'experiment' (4) is used to suggest danger and recklessness in terms of the outcome. The reference to tax (5) works to present Griffin as concerned with economic resources, (implicitly presented as unfairly distributed to non-Whites) rather than being racist; this is clearly an attempt at 'discursive deracialisation' (Augoustinos and Every, 2007). As in extract two the topic is changed without other speakers responding to this notion of an 'elite', instead Bonnie Greer challenges Griffin's use of the term 'British people'.

\section{(3B) $Q T$}

8. B.G. Nick who are the British people? Who are you talking about?

9. [two lines omitted]

10. N.G. the government's own figures according to demographers at

11. Oxford university show that the indigenous British (.) the people

12. who've been here

13. J.S. -the w- th- whites (.) the whites

14. N.G. no that's ir- (.) the skin colour's irrelevant

15. Jack skin [col[our's irrelevant ]

16. B.G? [yeah but what are you]

17. Aud [(boos and jeering and chatter for 3 second

18. J.S. [what- what it- what what do mean by white mister grif-] er 
19. o- indigenous? [you mean] white

20. N.G. [I think this] this gets to the very point...

21. [five lines omitted]

22. N.G. I think (.) we've (.) reached the absolute nub of it (.) no one here Jack

23. Straw wouldn't dare (.) to go to (.) New Zealand and say to a Maori 'what

24. do you mean indigenous?' (.) you wouldn't dare to go to (.) a- north

25. America and say to (.) an American Red Indian a Sioux or whatever

26. what do you mean indigenous we're all: the same (.) the indigenous

27. people of these islands the people the English the Scots the Irish and the

28. Welsh

29. J.S. -the whites (.)

30. the [whites ]

31. N.G. [the w- the ] colour (.) is (.)

32. [irrelevant (.)

33. J.S. -the whites

34. N.G. it's the people that have been here (.) overwhelmingly for the last]

35. Aud [(clapping and muttering from the audience for three seconds) ]

36. N.G. seventeen (.) thousand years (.) we are

37. the aborigines (.) here ] that's the

38. Aud [(some laughter for one second $)]$

39. N.G. si- [(.) y- yim- I- I- I'm sorry if you laugh if you want] to look at the

40. Aud [(audience muttering for two seconds)

41. N.G. scientific evidence online or whatever [read ] read the

42. Aud [(unclear shout)]

43. N.G . books by various scientists (.) the simple fact is that the majority of

44. the British people are descended from people who've lived here (.) since

$45 . \quad$ (.) time immemorial

46. J.S. -w- not not me

47. N.G. -[and it's extraordinarily racist (.) this ] is genuinely racist when

48. Aud [(shouting from the audience for one second)]

49. N.G. you seek to deny (.) the English -you people wouldn't even let us

50. have our name on the census form (.) that is racism (.) and that's why

51. people are

52. $\quad$ vo[ting (.) British National Party because we feel shut] out (.)in our 
54. own country they have erm gu- $\mathrm{u}$ - guided tours in the lake district

55. have been cancelled (.) because only (.) English people -white people (.)

56. we're going on them it erm

57. S.W what nonsense

58. All arguing from several members of the panel and noise from the audience

59. N.G. glouc- Gloucestershire police (.) no it's not Gloucestershire police] (.)

60. C.H. [another made up fact (.) absolute (.) absolute nonsense ]

61. N.G. Gloucestershire police turned

62. [down a hundred and eight (.) recruits because they were white]

63. C.H. [absolute nonsense this is- this is this is what

Throughout this extract, Griffin is repeatedly challenged over his use of the phrase the 'British people', a category construction that is consistently attacked for having racist connotations. Griffin attempts to construct the British people as the 'indigenous' people (11), a point which is bolstered through his reference to Oxford University. Despite this attempt, JS interrupts to imply that Griffin is racist, by suggesting that he is referring to colour (13). Griffin responds to JS by explicitly denying an interest in colour. The booing from the audience (17) at this point suggests that this denial has failed and that Griffin has overstepped culturally acceptable norms against prejudice. JS continues to push the point about colour.

At this point, rather than continuing to deny that he is interested in colour, a strategy that has resulted in jeers from the audience and sustained criticism from the panel, Griffin shifts and goes on the offensive (from line 20) and uses the strategy of claiming that the 'indigenous' people are the victims of racism. Griffin draws a parallel with other countries that have (non-white) indigenous groups who are known for their persecution by Europeans. By referring to these groups, Griffin attempts to present the indigenous people of Britain as comparable with these groups, and therefore equally as persecuted and at risk from invasion. Here indigenous British people are constructed as victims in a similar manner to Maori people and American Indians (see Edwards, 2012). At this point Griffin names the indigenous people (25), a construction which is again met by the implicit accusation by JS (29-30). Once more 
Griffin explicitly denies that he is interested in colour, but instead refers to length of time in the country and then describes the British 'us' as aborigines. This comment is met with laughter from the audience which Griffin responds to by attempting to build up the factual basis of his claim by referring to 'various scientists' (43).

Next, Griffin, who until now has been accused of racism, issues his own direct, and extreme, accusation of racism (47) by using the word 'extraordinarily' (47). By referring to this as 'genuinely racist' (47) Griffin is able to both deny any racism on his part while suggesting that racism does exist. Specifically, Griffin argues that racism is directed towards his (indigenous British) group, rather than this group being the cause of it. This point is used to account for the popularity of his party, a point that is met with a small amount of applause from the audience. Griffin then uses the words 'we' and 'our' to refer to the British groups, to whom the country is deemed to belong (50). This notion of ownership (and entitlement) is mirrored in the analysis of BNP voters by Rhodes (2011). Griffin then persists in presenting two examples of this racism towards the indigenous British majority. By conceptualising the indigenous majority as an oppressed group that is racially victimised, Griffin positions himself as someone protecting racial groups rather than attacking them: he is trying to prevent racism, rather than incite it. Interestingly, in giving these accounts of racism towards the majority group, Griffin refers to this group as 'white' (55 and 62). This linguistic slip provides some insight into racial agenda that Griffin previously attempted to avoid through the euphemistic employment of 'indigenous.' It is noteworthy that this slip occurs after a reference to 'English people' (55), where similar slips did not occur around the use of 'British' people. It is unclear why this slip may have happened here, although it could be explained by the different uses and meanings of the categories 'English' and 'British' (see Condor, 2000; 2006). Specifically, it has been suggested that the national category 'English' is avoided because of negative associations with imperialism (Condor, 2000). This contiguity of Englishness and 'white' has implications in respect to the extent to which fascism recalibration has occurred within the party. Both have racial overtones and are used when Griffin discusses entitlement and discrimination of the 'indigenous.'

64. [five lines omitted] 
65. D.D can the success of the BNP be explained by the misguided

66. immigration (.) policy which er the immigration policy you call the

67. greatest act of genocide against the British people in history according to

68. your website 'the immigration invasion an act of deliberate (.)

69. calculated (.) genocide (.) against our ancient race and nation' so (.)

70. $\quad$ successive governments (.) are committing genocide against their own

71. people is that your theory?

72. N.G. I'm afraid that's the case yeah that's certainly how it looks ]

73. D.D.

[that's your theory?]

74. Aud

$[($ muttering $)$

75. N.G. from- from- (.) from the ordinary grassroots position (.) when all the

76. political elite (.) celebrate (.) all the multicultural

77. diversity in [eh- eh (.) ever opened door

78. S.W. [do you know the definition of genocide?]

79. N.G. yes I do and it (.) is [about ]

80. S.W.

[what is the] definition [of genocide?

81. N.G.

[it's about destroying] (.) the

82. united nations definition (.) is about destroying a culture

83. [by not allowing children to learn their own culture (.) for example

84. S.W. [how appalling that you use that word in that way (.) how appalling

85. mister Griffin [that you use that word in that way]

After some discussion about whether or not Griffin is making up facts in the omitted lines, the chair goes on to refer to the government's immigration policy which, he claims, Griffin has referred to as an act of genocide (67/69/70). This claim, which he states comes from the party's website (mirroring their presentation of London bombings as an act of genocide by Muslims: Wood and Finlay, 2008), states that this genocide is 'deliberate' (68) and acting upon 'our ancient race' (69). This construction of 'our race' both draws upon an 'us and them' distinction (Leudar et al., 2004) which positions non-indigenous people as 'other', but it also explicitly refers to race. This claim is presented as outlandish through the use of the chair's rhetorical question (73). Despite this question being one that invites a 'no' response, Griffin responds by agreeing with it, albeit with the use of the term 'I'm afraid' (72) to highlight that this is deemed to be a serious problem. This response is met with a repetition of the chair's 
original question (73). As Griffin makes this claim, Baroness Warsi, the Conservative spokeswoman for community cohesion, twice refers to this claim as 'appalling' (84). While this claim is constantly challenged, in this extract Griffin again argues that it is indigenous British people that are the real victims of extreme racism, the first of the two strategies identified in this analysis.

It can be seen that precisely when Griffin makes some of his most contentious claims about the reversal of racism (such as those about British people being Aborigines and the victims of genocide) that references to the 'elite' (the second strategy identified) is made. An explicit reference to the elite comes at lines 76 when Griffin is making the contentious claim that there is genocide being committed against the British; again this is attributed to the 'political elite' who, for unexplained reasons, have promoted multiculturalism in Britain. This elite is once more contrasted with a British 'us' who are the 'ordinary grassroots' (75) people. Griffin positions himself as part of this later group, rather than as part of the elite, who are presented as out of touch with these 'normal' people. At no point when Griffin refers to the elite does another speaker pick up, or orient to, the notion of the elite; instead, in this case, the next speaker criticises his use of the term genocide.

\section{Discussion}

This analysis has explored how Griffin responds to accusations of extremism whilst appearing on high profile BBC programmes. Two interconnected strategies that were used by Griffin are identified. The first is that 'indigenous British' people are presented as the victims, not the perpetrators, of racism. The second is that Griffin blames this (alleged) racism towards ('indigenous') British people not on non'indigenous' groups (such as immigrants and ethnic minorities) but on an 'elite' from within Britain. These two strategies are mobilised together so that when Griffin attempts to draw attention to 'anti White' racism the blame is immediately placed on this elite. Consequently, his argument can be summarised as: the indigenous majority of the United Kingdom are discriminated against by a subset of the indigenous majority to the disadvantage of this majority.

Much of Griffin's talk is designed to avoid the omnipresent suggestion that he and the BNP are racist. In particular Griffin's attempts at avoiding the use of the category 
'White' throughout is of interest. By making classifications based on colour, Griffin risks presenting the BNP as interested in race, something that would undermine the process of 'fascism recalibration' (Copsey, 2007). This is why Griffin can regularly be seen to explicitly deny that he is talking about race, and also why his opponents (in particular Jack Straw) push this issue so strongly. It is, therefore, noteworthy that Griffin does, on occasion, refer to British people as 'white' (for example in extract 3B) as this suggests a slippage into the traditional far-right territory of colour-based policies and a partial failure of the BNP's attempted efforts to move away from its fascist past.

As Griffin appears to be so interested in denying any accusations of racism, it is therefore noteworthy that making counter-accusations of racism (that is directed towards 'British' people) is such a prominent strategy for two reasons. First, it highlights the notion of race, which is a potentially problematic area for the BNP to be publically discussing. Second, it also brings about the possibility of Griffin having to deal with all the problems associated with someone who makes accusations of racism (Goodman, 2010; Goodman and Burke, 2010) in addition to those associated with being accused of being a racist (e.g. Edwards 2003). It seems possible, therefore, that Griffin's counter-accusations of racism serve to deny the association of the party with racism (van Dijk, 1992, argues that reversal is a strong form of racism denial); indeed, Griffin only makes such accusations of anti-British racism in response to accusations of anti-minority racism directed towards him. Moreover, the extracts illustrate that the more challenging the accusation levelled at Griffin, the greater extremity of counteraccusation employed. Indeed, it is striking that Griffin's claim of genocide perpetration against the British people followed a panel consensus that Griffin's argument was predicated upon an interest in race and colour. Nevertheless this is a remarkable claim to make, and one that was oriented to as particularly outlandish.

Despite Griffin's attempts to avoid appearing racist, he nevertheless puts forward a strong opposition to multiculturalism; indeed it is this that is blamed for the 'genocide' of British culture. Multiculturalism is branded as particularly problematic and it is identified as the main problem in British society. For the far-right to refer to 
multiculturalism as problematic is perhaps to be expected as mainstream politicians have also strongly criticised it ${ }^{9}$.

The second part of the strategy used by Griffin is the reference to the elite (also referred to by Geert Wilders, Rooyacker and Verkuyten, 2012). This reference allows Griffin to disclaim potential accusations of racism by attributing the blame for this anti-White racism and enforced multiculturalism not to out-groups (as this would open him to accusations of racism) but to a third party. This third party is the 'elite', which is referred to in various terms: i.e., the 'political elite' (extracts one and three), the 'ruling elite,' and the 'liberal elite' (both extract two). Despite Griffin making a number of references to this 'elite', the group remains poorly defined. Indeed, group membership for this 'elite' appears somewhat arbitrary and might be described as those who do not conform to Griffin's position. The composition of this elite arguably serves a rhetorically fluid function (Edwards and Potter, 1992), attempting to align Griffin, rather than mainstream politicians, with the electorate. Indeed, historically, this attack on the 'elite' is seen in the antecedents for national-populism, wherein such groups purport to speak for the ordinary person and opposes the corrupt political establishment (Copsey, 2007). Alternatively, the vagueness in describing this group may function to veil extreme views. Since Griffin has previously distributed literature (Who are the Mind-Benders, 1997) claiming that a Jewish-led mass media is controlling the UK, it is possible that this lack of clarity in respect to the liberal elite functions to mask anti-Semitic conspiracy theories. Since Jews are the traditional target group for Nazis (Billig, 1978), this vagueness functions to distance the BNP from perceptions of far-right extremism. Removals of overt references to a Jewish elite may, therefore, be another feature of fascism recalibration.

Griffin omits to explain why 'elite' members of the indigenous majority should seek to disadvantage their own (racial) group to the advantage of another. What can be ascertained is that politicians (excluding those in the BNP) and the BBC are presented as being part of this elite. The references to an elite do appear to be somewhat conspiratorial and do not fit into mainstream understandings of power structures within the UK. Given the prominence that Griffin gives to this elite, it is noteworthy

\footnotetext{
${ }^{9}$ http://www.bbc.co.uk/news/uk-politics-12371994 Last accessed 26/11/12
} 
that at no point in these discussions does anyone else orient to this elite; if Griffin is attempting to discuss and discredit this group then he seems to have failed.

While neither of the strategies identified here are novel, this analysis is unique in that it has demonstrated how both these strategies are used in hostile political interactions and, significantly, how the two are employed together. It has demonstrated that counter accusations of racism directed at the elite by the far-right speaker become more extreme as the speaker becomes more harshly criticised. This analysis has therefore demonstrated the benefits of using a critical discursive approach as this methodology has allowed a detailed analysis of the strategies that Griffin uses while also allowing for this discussion of the political and social implications of using these strategies. However, the implications of this analysis may go far beyond a greater understanding of the management of rhetoric by Griffin, as such strategies can have far reaching implications. For example, it is noteworthy that the argument being used by Griffin has been used more recently by Anders Breivik, who carried out attacks in Norway in 2011. Breivik is a far-right activist who described the attacks as being in self defence because of the multiculturalism being imposed on Norway (strategy one). He acted against those that he claimed were part of this elite (strategy two), who he referred to as "traitors' 10 in the form of the Norwegian Labour Party. While it is not being claimed that supporters of the BNP are about to commit such acts, it is important to recognise the similarities in these arguments.

\section{Conclusions}

This analysis has shown that when faced with hostile criticism in mainstream political programmes, Griffin uses two inter-related strategies to justify his position. Griffin attempts to reposition 'indigenous' British people as the 'true' victims of racism in the country. As Griffin does this he is careful not to blame any minorities, but instead a powerful 'elite' from within the country. Griffin appears to have failed in any attempts to highlight this elite as a cause of problems for Britain and has only limited success in positioning British people as victims of racism; instead having to deal with difficult challenges about the racist motivations of his own party. It seems, therefore, that the BNP's attempted 'fascism recalibration' (Copsey, 2004) has, as yet, been unsuccessful.

\footnotetext{
${ }^{10}$ http://www.independent.co.uk/news/world/europe/anders-breivik-admits-massacre-but-pleads-notguilty-claiming-it-was-self-defence-7647009.html Last accessed 20/12/12
} 
This analysis therefore contributes to the literature on the talk of the far right by demonstrating how Griffin attempts, and to a large degree fails, to bring about 'fascism recalibration' and how he attempts to deal with the problematic criticisms that he faces when making rare (and controversial) appearances in mainstream British media broadcasts. To date no studies have addressed this, so these findings are novel. By highlighting the strategies that Griffin uses, those that seek to oppose the BNP, and the far-right more broadly, may be able to use these findings to draw attention to the problems with their position and to produce more effective counter arguments.

The lack of success of Griffin's rhetoric is further evidenced via a number of recent electoral setbacks for the party. The appearances analysed in the current manuscripts occurred prior to the 2010 General Election, and whilst percentage of the vote increased in the General Election (1.9\% up from $0.7 \%$ in 2005 ), the party experienced a net loss of 11 councillors in 2011, lost all six defending council seats in 2012, and lost their sole London Assembly Member in 2012. This suggests that Nick Griffin was unable to counter the accusations of extremism and that greater exposure to critique of the party deterred voters. Moreover, in the coming years, it will be of interest to observe the extent to which support for the BNP is squeezed at both the ends of the right-wing spectrum. The less toxic brand of the (anti-immigration) United Kingdom Independence (UKIP) party may attract moderate BNP supporters (and indeed polled strongly in the 2013 Eastleigh by-election with $27.8 \%$ of the vote). Whereas the English Defence League (EDL), an anti-Islamic far-right street protest group, may attract BNP supporters disenfranchised by their process of modernisation. The 2014 European Parliament Elections will be a clear test of the enduring popularity of the BNP and will explore if their 2009 success was anomalous.

\section{References}

Antaki, C. \& Leudar, I. 2001. Recruiting the Record: Using Opponents' Exact Words in Parliamentary Argumentation. Text. 21(4), 467-488.

Atton C. 2006. Far-right media on the internet: culture, discourse and power. New Media Society. 8(4), 573-587. 
Augoustinos, M., \& Every, D. 2007. The language of "race' and prejudice: A discourse of denial, reason, and liberal-practical politics. J. Lang. Soc. Psychol. 26, $123-141$.

Billig, M. 2012. Humour and hatred: the racist jokes of the Ku Klux Klan. Discourse Soc. 12(3), 267-289.

Billig, M. 1988. The Notion of 'Prejudice': Some Rhetorical and Ideological Aspects. Text. 8(1-2), 91-110.

Billig, M. 1978. Fascists: A social psychological view of the National Front. London: Academic Press.

Clarke, V., Kitzinger, J. \& Potter, J. 2004 "Kids are just cruel anyway": Lesbian and gay parents' talk about homophobic bullying. British Journal of Social Psychology. 43(4), 531-550.

Clayman, S. \& Heritage, J. 2002. The News Interview: Journalists and Public Figures on the Air. Cambridge: Cambridge University Press.

Condor, S. (2006). Temporality and collectivity: diversity, history and the rhetorical construction of national entitativity. British Journal of Social Psychology. 45, 657682.

Condor, S. (2000). Pride and prejudice: identity management in English people's talk about 'this country'. Discourse and Society. 11, 175-205.

Copsey, N. 2007. Changing course or changing clothes? Reflections on the ideological evolution of the British National Party 1996-2006. Patterns Prejudice. 41(1), 61-82.

Copsey, N. 2004. Contemporary British Fascism: The British National Party and the Quest for Legitimacy. Basingstoke: Palgrave. 
Deary, I.J., Batty, .G.D., \& Gale, C.R. 2008. Childhood intelligence predicts voter turnout, voting preferences, and political involvement in adulthood: The 1970 British Cohort Study. Intelligence. 36, 548-555.

Edwards, G.O. 2012. A comparative discourse analysis of the construction of 'ingroups' in the 2005 and 2010 manifestos of the British National Party. Discourse Soc. 23(3), 245-258.

Edwards, D. 2003. Analyzing Racial Discourse: The Discursive Psychology of MindWorld Relationships. In: Van den Berg, H., Wetherell, M., \& Houtkoop-Steenstra, H. (eds). Analyzing Race Talk: Multidisciplinary Approaches to the Interview. Cambridge: Cambridge University Press, pp. 31-48.

Edwards, D. \& Potter, J. 1992. Discursive Psychology. London: Sage.

Ford, R. \& Goodwin, M. 2010. Angry White Men: Individual and Contextual Predictors of Support for the British National Party. Polit. Stud-London. 58, 1-25.

Goodman, S. 2010. "It's not Racist to Impose Limits on Immigration": Constructing the Boundaries of Racism in the Asylum and Immigration debate. Critical Approaches to Discourse Analysis across disciplines. 4(1), 1-17

Goodman, S. 2008. Justifying the Harsh Treatment of Asylum Seekers on the Grounds of Social Cohesion. Annual Review of Critical Psychology. 6, 110-124.

Goodman, S. \& Burke, S. 2011. Discursive deracialization in talk about asylum seeking. J Community Appl Soc. 21(2), 111-123.

Goodman, S. \& Burke, S. 2010. “Oh you don't want asylum seekers, oh you're just racist": A discursive analysis of discussions about whether it's racist to oppose asylum seeking. Discourse Soc. 2(3), 325-340 
Halikiopoulou, D. \& Vasilopoulou, S. 2010. Towards a 'civic' narrative: British national identity and the transformation of the British National Party. Polit. Quart. 81(4), 584-592.

Leudar, I., Marsland, V. \& Nekvapil, J. 2004. On Membership Categorisation: 'Us', 'Them' and 'Doing Violence' in Political Discourse. Discourse Soc. 15(2-3), 243266.

Potter, J. \& Wetherell, M. 1987. Discourse and Social Psychology, Beyond Attitudes and Behaviour. London, Sage.

Renton, D. 2005. 'A day to make history'? The 2004 elections and the British National Party. Patterns Prejudice. 39(1), 25-45.

Rhodes, J. 2011. 'It's not just them, it's whites as well': Whiteness, class and BNP support. Sociology. 45(1), 102-117.

Rhodes, J. 2009. The political breakthrough of the BNP: The case of Burnley. British Politics. 4(1), 22-46.

Rooyackers I.N. \& Verkuyten M. 2012. Mobilizing support for the extreme right: A discursive analysis of minority leadership. Brit. J. Soc. Psychol. 51, 130-148.

Treadwell, J. 2012. White riot: the English Defence League and the 2011 English Riots. Criminal Justice Matters. 87(1), 36-37.

van der Valk, I. 2003. Right-Wing Parliamentary Discourse on Immigration in France. Discourse Soc. 14(3), 309-348.

van Dijk, T.A. 1993. Denying Racism: Elite Discourse and Racism. In J. Solomos \& J. Wrench (eds.) Racism and Migration in Western Europe. (pp. 179-193). Oxford: Berg. 
Verkuyten, M. 2012. Justifying discrimination against Muslim immigrants: Out-group ideology and the five-social identity model. Brit. J. Soc. Psychol. DOI: $10.1111 / \mathrm{j} .2044-8309.2011 .02081 . x$

Wetherell, M. 2003. Racism and the Analysis of Cultural Resources in Interviews. In: Van den Berg H, Wetherell M, and Houtkoop-Steenstra H (eds) Analyzing Race Talk: Multidisciplinary Approaches to the Interview. Cambridge; Cambridge University Press, pp. 11-30.

Wood, C \& Finlay, W. M. L. 2008. British National Party representations of Muslims in the month after the London bombings: Homogeneity, threat, and the conspiracy tradition. Brit. J. Soc. Psychol. 47, 707-726.

Woodbridge, S. 2010. Christian credentials? The role of religion in British National Party ideology. Journal for the Study of Radicalism. 4(1), 25-54.

\subsection{Web References}

\subsubsection{Full Interviews}

Today (BBC Radio 4, $8^{\text {th }}$ June 2009). Audio file, retrieved from: http://news.bbc.co.uk/today/hi/today/newsid_8088000/8088793.stm (last accessed 26th of November, 2012)

Question Time (BBC1, 22 ${ }^{\text {nd }}$ October 2009). Video file, retrieved from http://www.bbc.co.uk/programmes/b00nft24 - This programme can now be found on youtube - http://www.youtube.com/watch?v=xlLa54S-Usc (last accessed 26th of November, 2012).

Radio Five Live Breakfast (Radio 5 Live, $19^{\text {th }}$ of April 2010). Audio file, retrieved from (beginning at 5 minutes 12 seconds into the file):

http://www.bbc.co.uk/programmes/b00s1tlr (last accessed 26th of November, 2012) 


\subsubsection{Other Online Sources}

Democracy, Freedom, Culture and Identity: The British National Party Electoral Manifesto (2010). Retrieved from:

http://communications.bnp.org.uk/ge2010manifesto.pdf (last accessed 26th of November, 2012)

British National Party Website. Retrieved from: http://www.bnp.org.uk/ (last accessed $21^{\text {st }}$ of December, 2012)

Robinson, J., Conlan, T., Sweney, M. (2009, October 23). BBC relief turns to anxiety as public say Nick Griffin was 'picked-on'. Retrieved from:

http://www.guardian.co.uk/politics/2009/oct/23/bbc-anxiety-nick-griffin (last accessed 20th December, 2012)

Hall, J. (2012, April 16). Anders Breivik admits massacre but pleads not guilty claiming it was self defence.

http://www.independent.co.uk/news/world/europe/anders-breivik-admits-massacrebut-pleads-not-guilty-claiming-it-was-self-defence-7647009.html (last accessed 20th December, 2012) 